\title{
CORRECTION
}

\section{Correction to: Low Fluctuation of Symptoms May Delay Diagnosis of Myasthenia Gravis: A Case Series}

\author{
Andreea Dragusin • Nicolae Grecu • Athena Cristina Ribigan (D) • \\ Raluca Stefania Badea · Elena Oana Terecoasa · Amalia Ene • \\ Cristina Tiu
}

Published online: January 23, 2022

(C) The Author(s) 2022

Correction to: Neurol Ther https://doi.org/10.

1007/s40120-021-00312-w

In this article the statement in the funding information section was incorrectly given as "The Rapid Service Fee was funded by CMI DR ANTOCHI FLORINA ANCA-NEUROLOGIE ULTRASONOGRAFIE DOPPLER VASCULARA" and should have read: "The Rapid Service Fee was funded by the authors".

The original article has been corrected.

\section{OPEN ACCESS}

This article is licensed under a Creative Commons Attribution-NonCommercial 4.0 International License, which permits any non-

The original article can be found online at https://doi. org/10.1007/s40120-021-00312-w.

A. Dragusin · N. Grecu · A. C. Ribigan $(\bowtie)$.

R. S. Badea - E. O. Terecoasa - A. Ene - C. Tiu

Neurology Department, University Emergency

Hospital of Bucharest, 169 Splaiul Independentei,

050098 Bucharest, Romania

e-mail: athena.ribigan@umfcd.ro

A. C. Ribigan · R. S. Badea - E. O. Terecoasa - C. Tiu

"Carol Davila" University of Medicine and

Pharmacy, 8 Bulevardul Eroii Sanitari, 050474

Bucharest, Romania commercial use, sharing, adaptation, distribution and reproduction in any medium or format, as long as you give appropriate credit to the original author(s) and the source, provide a link to the Creative Commons licence, and indicate if changes were made. The images or other third party material in this article are included in the article's Creative Commons licence, unless indicated otherwise in a credit line to the material. If material is not included in the article's Creative Commons licence and your intended use is not permitted by statutory regulation or exceeds the permitted use, you will need to obtain permission directly from the copyright holder. To view a copy of this licence, visit http://creativecommons.org/licenses/by$\mathrm{nc} / 4.0 /$. 